\title{
ECLETICA
}

WWW.scielo.br/eq

Volume 30, número 3, 2005

\section{Spectrophotometric study of iron oxidation in the iron(II)/thiocyanate/acetone system and some analytical applications}

\author{
F. G. Martins, J. F. Andrade, A. C. Pimenta, L. M. Lourenço, \\ J. R. M. Castro, V. R. Balbo \\ Departamento de Química, FFCLRP-USP, Av. Bandeirantes, 3900 (Campus da USP), 14040-901, Ribeirão Preto, \\ SP, Brazil.
}

\begin{abstract}
The possibility of using thiocyanate to determine iron(II) and/or iron(III) in water-acetone mixture has been re-examined as part of a systematic and comparative study involving metallic complexes of pseudohalide ligands. Some parameters that affect the complete oxidation of the ferrous cations, their subsequent complexation and the system stability have been studied to optimize the experimental conditions. Our results show the viability and potentiality of this simply methodology as an alternative analytical procedure to determine iron cations with high sensitivity, precision and accuracy. Studies on the calibration, stability, precision, and effect of various different ions have been carried out by using absorbance values measured at $480 \mathrm{~nm}$. The analytical curve for the total iron determination obeys Beer's law $(\mathrm{r}=0.9993)$, showing a higher sensitivity (molar absorptivity of $2.10 \times 10^{4} \mathrm{~L} \mathrm{~cm}^{-1} \mathrm{~mol}^{-1}$ ) when compared with other traditional systems (ligands) or even with the "similar" azide ion $\left[1.53 \times 10^{4} \mathrm{~L} \mathrm{~cm}^{-1} \mathrm{~mol}^{-1}\right.$, for iron-III/azide complexes, in $70 \%$ (v/v) tetrahydrofuran/water, at $396 \mathrm{~nm}$ ]. Under such optimized experimental conditions, it is possible to determine iron in the concentration range from 0.5 to $2 \mathrm{ppm}$ (15-65\% T for older equipments, quartz cells of $1.00 \mathrm{~cm})$. Analytical applications have been tested for some different materials (iron ores), also including pharmaceutical products for anemia, and results were compared with atomic absorption determinations. Very good agreement was obtained with these two different techniques, showing the potential of the present experimental conditions for the total iron spectrophotometric determinations (errors $<5 \%$ ). The possibility of iron speciation was made evident by using another specific and auxiliary method for iron(II) or (III).
\end{abstract}

Keywords: iron(II/III)-thiocyanate-acetone system; oxidation; spectrophotometric applications.

\section{Introduction}

Studies on complexes formation, their respective stabilities (equilibria) and/or analytical utilization have been accomplished in a systematic way in some laboratories, especially when systems involving pseudohalide or halide ligands with transition metal cations [1-13] are concerned. The intense red colour characteristic of the compounds formed between iron(III) and thiocyanate ions in acidic aqueous medium is one of the strongest evidences of the chemical analogy existing between these species $\left(\mathrm{SCN}^{-}\right)$and azide $\left(\mathrm{N}_{3}\right)$ ligands.

In spectrophotometric studies, the presence of organic solvent in the reaction systems generally increases the complexes stability and consequently the molar absorptivity and the sensitivity. The fading of the iron(III)/thiocyanate colour has been a very critical photometric problem in aqueous medium and a large number of classic works have been carried towards the stabilization of such iron(III) complexes[14,15]. More recently[12], another spectrophotometric oxidation study using the iron(II)/azide/tetrahydrofuran system was done 
in our laboratory, which allowed us to explore a new band ( $396 \mathrm{~nm})$, also described by our group in the literature, caused exclusively by the THF presence under a large excess of the azide ligand[7].

In present work, as part of these continuing comparative studies, we investigated the oxidation potentialities of the ferrous system and its subsequent stability, using a more usual and low cost ligand (thiocyanate).

Iron (from the Latin, ferrum) is the fourth most abundant element on Earth's crust and nucleus[16,17]. Among its physical properties, the most important one is its magnetism, which can be observed at room temperature. In nature, iron occurs mainly as hematite $\left(\mathrm{Fe}_{2} \mathrm{O}_{3}\right)$. Its pure form presents few practical uses, but iron finds many useful applications when it is mixed with certain chemical elements such as carbon, manganese, chromium, nickel or titanium, leading to the formation of alloys that display extremely interesting properties[18]. In spite of all its applications, iron possess is the undesirable problem of easily undergoing corrosion. That is why it is not found as a single element in nature[19]. Biologically, iron is a nutrient that has important functions in human metabolism, like the physiological production of hemoglobin and the transport of oxygen in the blood[20-22].

The $\mathrm{SCN}^{-}$ligand can bind to a metal ion through either its $\mathrm{S}$ or $\mathrm{N}$ atom, resulting in the corresponding thiocyanate and isothiocyanate complexes, respectively[23-25]. The change in coordination type from M-SCN to M-NCS is related to the metal type; that is, the "hard and soft acids". In the case of soft acids, the binding occurs through the $\mathrm{S}$ atom, giving rise to thiocyanates. The $\mathrm{SCN}^{-}$ ion can act as a ligand, exerting marked influence on the complex stability and structure, among other properties.

In the literature, the large importance of different methodologies for iron(II), iron(III) or total iron(with speciation) determinations can be noted through several techniques[26-31]. Bearing this in mind, the main purpose of this work was examine and use the optimized experimental conditions for a rapid and complete oxidation of iron(II) cations in the ferrous-thiocyanate system. So, parameters such as acidity of the reactional medium, ligand concentration, temperature and the presence of different organic solvents were verified. The oxidation progress was controlled by comparing the absorbance values measured in some studies with a standard solution of iron(III) prepared exactly under the same tested conditions. The main advantage of acetone in this simple system is the fact that it acts as auxiliary oxidizing agent and complex stabilizer allowing very sensitive spectrophotometric determinations (total iron or speciation), besides being inexpensive and, thus, easily affordable.

\section{Material and methods}

Most of the spectrophotometric measurements were carried out at $25.0^{\circ} \mathrm{C}$, with a DU-70 BECKMAN spectrophotometer, using stoppered quartz cells of $1.00 \mathrm{~cm}$ optical path length. Comparative measurements by atomic absorption were done with an instrument SHIMADZU, AA-680, to check the validity of the spectrophotometric determinations.

The study on temperature effect was accomplished using a TE-184 Tecnal Thermostatic Bath for the adjustment of the different values in the reaction flasks and cells.

All potentiometric titrations employed to standardize different solutions were carried out using a common Micronal pH meter, model B-374, and its appropriate electrodes. A piston buret (Metrohm, 5.00 or $10.00 \mathrm{~mL}$ ) was used for the addition of standardized reagents.

All reagents were purchased from Merck, Aldrich or Mallinckrodt (Analytical grade).

Different potentiometric standardizations were accomplished with sodium hydroxide, silver nitrate, and EDTA solutions, being their respective concentrations $0.0994 ; 0.0876$ and $0.0461 \mathrm{~mol} \mathrm{~L}^{-1}$. Such solutions had been previously standardized with standard solutions of potassium hydrogen phthalate, potassium chloride and zinc, respectively.

An iron(III) stock solution $\left(4.31 \times 10^{-2}\right.$ mol L ${ }^{-1}$ ) was prepared using the ammonium and iron(III) sulfate salt, $\left(\mathrm{NH}_{4} \mathrm{Fe}\left(\mathrm{SO}_{4}\right)_{2} \cdot 12 \mathrm{H}_{2} \mathrm{O}\right)$, in perchloric acid medium ( $\mathrm{pH} 1-2)$, to prevent hydrolysis. It was used as a control solution to indicate which would be the maximum absorbance value $\left(\mathrm{A}_{480}=1.07\right.$, under the best conditions $)$ that should be reached by the ferrous solution in all 
the different studies; in other words, this reference solution was used to show how complete the oxidation process was.

Iron(II) stock solutions $\left(8.99 \times 10^{-3} \mathrm{~mol} \mathrm{~L}^{-1}\right)$ were prepared using the Mohr salt, $\left(\mathrm{NH}_{4}\right)_{2} \mathrm{Fe}\left(\mathrm{SO}_{4}\right)_{2} \cdot 6 \mathrm{H}_{2} \mathrm{O}$. Before each preparation, oxygen was removed from the distilled water by nitrogen bubbling, in order to guarantee that just ferrous species would be present in the stock solution. Since the oxidation of iron(II) to iron(III) is spontaneous in the presence of atmospheric oxygen, such ferrous solutions could not be stocked for long periods. During the preparations, these solutions were also acidified with perchloric acid ( $\mathrm{pH}$ 1-2) for stabilization.

A perchloric acid solution $\left(2.94 \mathrm{~mol} \mathrm{~L}^{-1}\right)$ was standardized with sodium hydroxide by potentiometric titration, using a combined glass electrode. All solvents employed, e.g., acetone (Mallinckrodt), were used without any previous treatment. The sodium thiocyanate solution ( $\mathrm{NaSCN}),\left(2.86 \mathrm{~mol} \mathrm{~L}^{-1}\right)$ was standardized by precipitation titration, using a standard silver nitrate solution and an $\mathrm{Ag} / \mathrm{AgCl}$ combined electrode.

Interference studies of diverse ions were carried out using the respective sources of saline solutions, approximately $0.2 \mathrm{~mol} \mathrm{~L}^{-1}$ each, preferably employing nitrates (for different cations) and sodium (for anions) due to their easy accessibility and well known low coordination capacity (avoiding competition with the main ligand).

Two samples of hematite rocks were analyzed. They were prepared at a concentration about $160 \mathrm{mg} \mathrm{L}^{-1}$, by weighing exactly 0.1100 grams of each rock, which were then transferred to a beaker. Under stirring and heating, concentrated $\mathrm{HClO}_{4}(30 \mathrm{~mL})$ and $\mathrm{HCl}(50 \mathrm{~mL})$ solutions were added to the rocks to guarantee their complete and fast dissolution. A boiling treatment followed by several successive additions of water was done to evaporate all chloride excess. The solution was quantitatively transferred to a volumetric flask $(500 \mathrm{~mL})$ and completed to the mark with distilled water.

The pharmaceutical drug for anaemia (IRONFER $^{\circledR}$, Laboratory Chemical Union, $\mathrm{FeSO}_{4} \cdot 7 \mathrm{H}_{2} \mathrm{O}$ ) contains $40 \mathrm{mg}$ of elementary iron in each tablet, according to the manufacturer. To open the tablet covering (metacrylic acid copolimer), distilled water $(10 \mathrm{~mL})$ and concentrated $\mathrm{HClO}_{4}(15 \mathrm{~mL})$ were added to an erlenmeyer flask containing the drug, under careful heating and stirring. At this stage, the solution acquired a black color. Soon afterwards, small and successive portions of activated coal were added to the flask, also under vigorous stirring. After a brief decantation period, the solution was filtered under vacuum using suitable paper and funnil to retain the coal. The filtrate was quantitatively transferred to an erlenmeyer flask and submitted to heating to reduce its volume. After some hours, the solution was quantitatively transferred to a volumetric flask $(25 \mathrm{~mL})$ and completed with distilled water to the mark. The resulting final solution $\left(1.43 \times 10^{-2} \mathrm{~mol} \mathrm{~L}^{-1}\right)$ was limpid and stable.

\section{Results and discussion}

Our main objective was gather the best experimental conditions for complete oxidation and complexation reactions in the iron(II)/ thiocyanate system, making its fast spectrophotometric utilization possible. The dependence of the colour intensity of the formed iron-thiocyanate complexes on the nature and concentration of the acid anion have seen studied[14,15]. Perchloric acid has been chosen to acidify this system (and analogous ones) due to its weak coordination character. Among the more common inorganic acids, sulfuric is certainly the less recommended because of its strong complexing power (competitive anions) $[5,7,9]$.

Acidification is necessary to prevent iron hydrolysis. At first, based on some previous experimental conditions[12], the acidity effect was verified by using solutions containing a fixed concentration of iron(II) (2.79 ppm), thiocyanate $\left(250 \mathrm{mmol} \mathrm{L}^{-1}\right)$ and acetone $[70 \%(\mathrm{v} / \mathrm{v})]$, but different concentrations of perchloric acid $(30,50$, 100, 200 and $\left.400 \mathrm{mmol} \mathrm{L}^{-1}\right)$. In this concentration range (Fig. 1), no significant change was observed in the maximum absorbance value. Our main interest was to force rapid oxidation and complexation of the iron ions without caring about the species (complexes iron/thiocyanate) formed. Higher sensitivity and stability of the system are always very important factors for the development of analytical applications. 


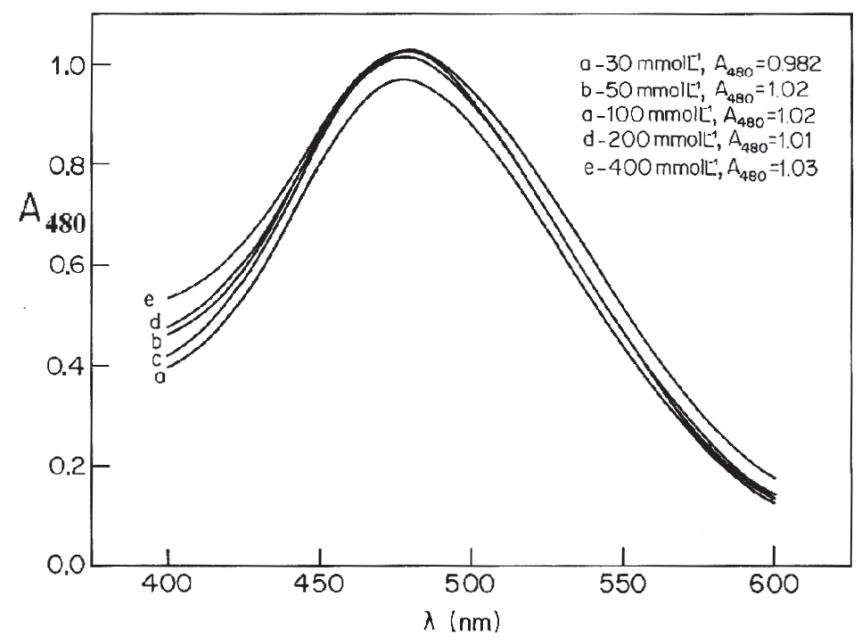

Figure 1. Effect of perchloric acid concentration on the absorption spectra of the iron/SCN $\mathrm{SN}^{-}$system.

$\mathrm{C}_{\text {acetone }}=70 \%(\mathrm{v} / \mathrm{v}), \mathrm{C}_{\mathrm{SCN}^{-}}=250 \mathrm{mmol} \mathrm{L}^{-1}, \mathrm{C}_{\mathrm{HClO}_{4}}=$ variable $\left(30-400 \mathrm{mmol} \mathrm{L}^{-1}\right), \mathrm{C}_{\mathrm{Fe}}{ }^{2+}=0.05 \mathrm{mmol} \mathrm{L}^{-1}(2.79$ $\mathrm{ppm}), \mathrm{C}_{\mathrm{H}_{2} \mathrm{O}_{2}}=5 \mathrm{drops}(30 \% \mathrm{w} / \mathrm{w}), \mathrm{T}=25.0^{\circ} \mathrm{C}$ and reaction time $=5 \mathrm{~min}$.

In some of the tests carried out for this work, it was observed that excess of peroxide may cause a yellowish interfering colour due to oxidation products of the thiocyanate ligand. In this way, addition of hydrogen peroxide to the reaction medium to aid oxidation was abandoned in the following studies. Other oxidizing agents were also previously tried without any satisfactory result.

In the following stage, iron(II) (2.79 ppm) and perchloric acid $\left(30 \mathrm{mmol} \mathrm{L}^{-1}\right)$ concentrations were kept constant, and the thiocyanate concentration was varied $(100,150,200,250,350$, and $\left.550 \mathrm{mmol} \mathrm{L}^{-1}\right)$. Fig. 2 shows that higher ligand concentrations favour the complexation of the system, making it more sensitive. A thiocyanate concentration of $250 \mathrm{mmol} \mathrm{L}^{-1}$ is enough to promote rapid oxidation of iron(II) to iron(III), as well as its subsequent complexation, whose stability is one of the main objectives of the study.

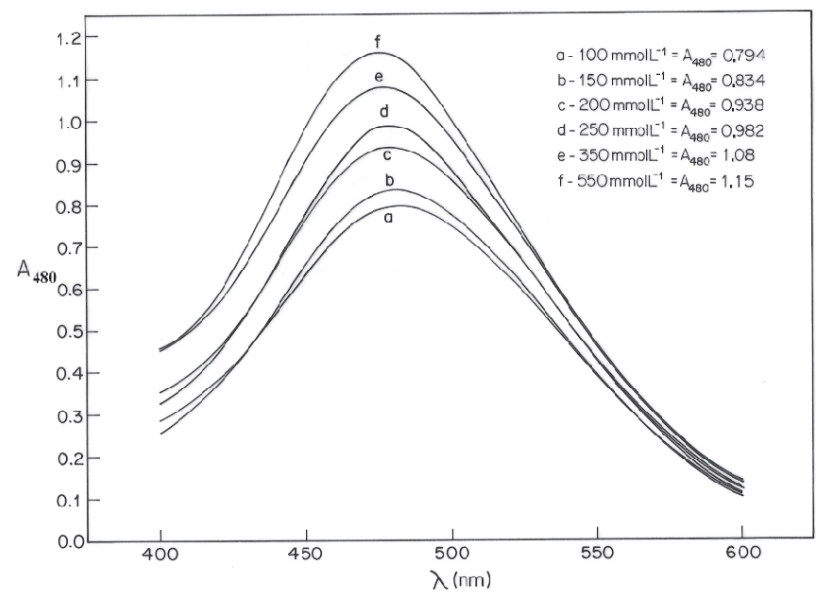

Figure 2. Effect of thiocyanate concentration on the maximum absorption.

$\mathrm{C}_{\mathrm{HClO}_{4}}=30 \mathrm{mmol} \mathrm{L}^{-1}, \mathrm{C}_{\text {acetone }}=70 \%(\mathrm{v} / \mathrm{v}), \mathrm{C}_{\mathrm{SCN}^{-}}=$(variable) $100-550 \mathrm{mmol} \mathrm{L}^{-1}$, $\mathrm{C}_{\mathrm{Fe}}{ }^{2+}=0.05 \mathrm{mmol} \mathrm{L}^{-1}(2.79 \mathrm{ppm}), \mathrm{T}=25.0^{\circ} \mathrm{C}$ and reaction time $=5 \mathrm{~min}$. 
A parallel study showed that the oxidation rate is not significantly influenced by changes in temperature. So, all the further studies were carried out at $25^{\circ} \mathrm{C}$. In Fig. 3 , an identical iron(III) solution was also used as reference ( $100 \%$ oxidation).

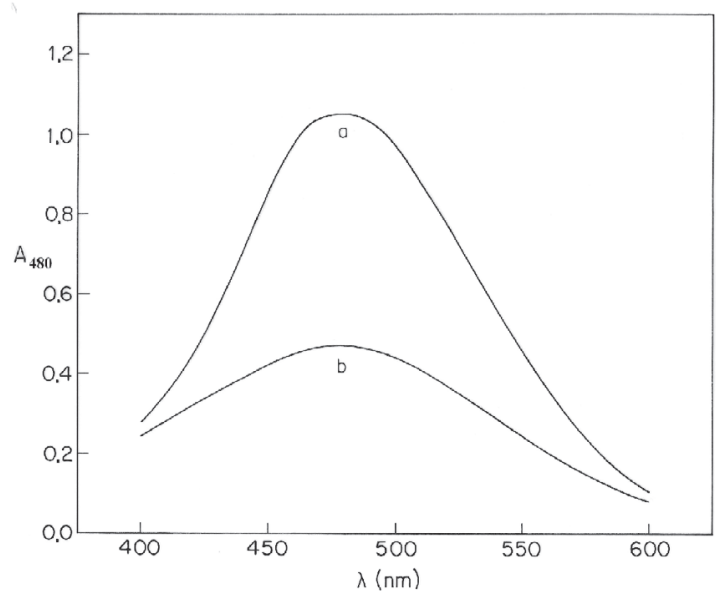

Figure 3. Influence of acetone on the spectrum of the iron(III)/thiocyanate system.

(b) $\mathrm{C}_{\mathrm{HClO}_{4}}=30 \mathrm{mmol} \mathrm{L}^{-1}, \mathrm{C}_{\mathrm{SCN}^{-}}=250 \mathrm{mmol} \mathrm{L}^{-1}$ and $\mathrm{C}_{\mathrm{Fe}}{ }^{3+}=0.05 \mathrm{mmol} \mathrm{L}^{-1}(2.79 \mathrm{ppm})$.

(a) Conditions of (b) $+\mathrm{C}_{\text {acetone }}=70 \%(\mathrm{v} / \mathrm{v}), \mathrm{T}=25.0$ ${ }^{\circ} \mathrm{C}$ and reaction time $=5 \mathrm{~min}$.

The presence of organic solvents normally favors the formation of compounds (complexes) due to their well-known solvation effects. Acetone was the organic solvent of choice since it is a reagent commonly used in laboratories, which had already been applied in other studies by our research group[5]. This maximum absorption value of curve (a), Fig. 3, was used as reference to indicate the system complete oxidation, $\left(\mathrm{A}_{480}=1.07\right.$, under the best conditions $)$.

A simple methodology for the simultaneous determination of iron(II) and iron(III) (speciation) could then be easily proposed, completing the present procedure. For this purpose, it would be necessary to use some classic and specific determination method to aid analysis of only one of the two oxidation states [Fe(II) or Fe(III)] of metal. For example, when the Fe(III)/ $\mathrm{SCN}^{-}$system was used in aqueous medium, which permits the determination of iron(III) only, its linear plot $(y=0.192 x$, with $r=0.9998)$ yielded an average molar absorptivity of $1.07 \times 10^{4} \mathrm{~L} \mathrm{~cm}^{-1} \mathrm{~mol}^{-1}$. The presence of $\mathrm{Fe}$ (II) does not interfere with $\mathrm{Fe}$ (III) determination under these conditions, because the iron(II) complexes are unstable, and the angular coefficient is practically of the same order of magnitude $(y=0.198 x$ and average molar absorptivity of $\left.1.10 \times 10^{4} \mathrm{~L} \mathrm{~cm}^{-1} \mathrm{~mol}^{-1}\right)$. In this way, the determination of the total iron concentration can be accomplished in the conditions proposed here, and the iron(II) concentration could then be finally obtained by the difference between the total iron and iron(III) concentrations.

The analytical curve for this procedure was obtained under the best experimental conditions (see Fig. 4). The linear plot $(y=0.3757 x$, with $r=0.9993)$ yielded an average molar absorptivity of $2.10 \times 10^{4} \mathrm{~L} \mathrm{~cm}^{-}$ ${ }^{1} \mathrm{~mol}^{-1}$, at $480 \mathrm{~nm}$, for the total iron [iron(II) + iron(III)] present in the solution.

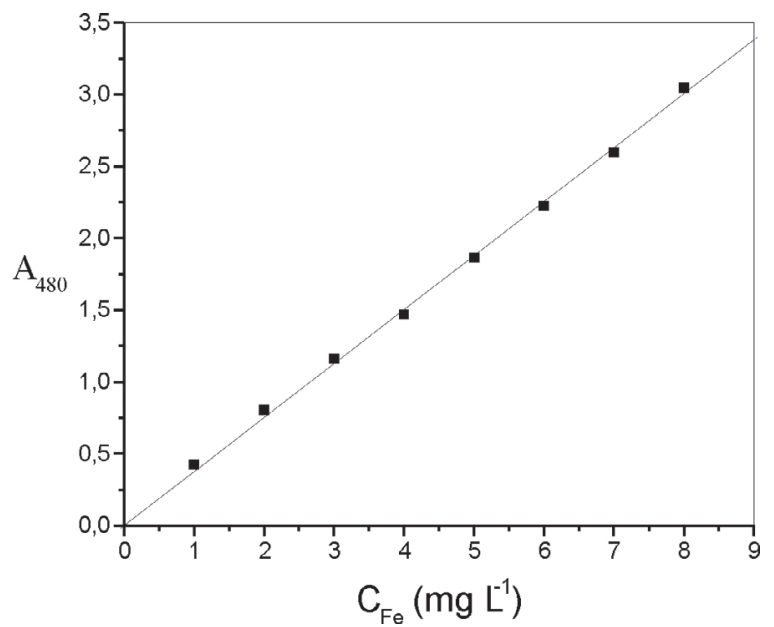

Figure 4. Verification of Beer's law for total iron in the presence of iron/thiocyanate system, under the best experimental conditions. 
Precision and stability studies were also carried out. Twenty samples of iron were equally prepared and measured. The average absorbance value was $\hat{\mathrm{A}}=1.03$; absolute average deviation = 0.01 ; standard deviation $=0.013$ and confidence limit $(95 \%)=1.03 \pm 0.01$. In the stability study, one sample $\left(\mathrm{A}_{480}=1.05\right)$ was observed during a continuous period of $6 \mathrm{~h}$, in different time intervals, showing very low variation in the absorbance value after this period.

Very good complex stability (after 360 minutes $\mathrm{A}_{480}=1.06 ; \Delta \mathrm{A}_{480}=0.01$ or $1 \%$ ) was verified. The prepared samples were allowed to stand 5 min before each measurement, to guarantee complete reaction

Once the analytical method for iron determination was established, the next step was to find out which ionic species could interfere with the spectrophotometric values. Several cations and anions were individually introduced in the sample. The absorbance values were compared with that of the respective reference sample, at $480 \mathrm{~nm}$, since this control contained no additional (diverse) ions. Percent errors were calculated for each species individually. Among the cations and anions studied, $\mathrm{Cl}, \mathrm{HCO}_{3}^{-}, \mathrm{SO}_{4}{ }^{2-}, \mathrm{SO}_{3}{ }^{2-}, \mathrm{NO}_{3}^{-}, \mathrm{BrO}_{3}^{-}, \mathrm{OH}^{-}, \mathrm{ClO}_{3}^{-}$, $\mathrm{ClO}_{4}^{-}, \mathrm{N}_{3}^{-}, \mathrm{HCOO}^{-}, \mathrm{NH}_{4}^{+}, \mathrm{Li}^{+}, \mathrm{Ca}^{+2}, \mathrm{~K}^{+}, \mathrm{Al}^{3+}, \mathrm{Mn}^{2+}$, $\mathrm{Cd}^{2+}, \mathrm{Ba}^{2+}, \mathrm{Na}^{+}, \mathrm{Hg}^{2+}, \mathrm{Zn}^{2+}, \mathrm{Cr}^{2+}$ did not interfere with measurements when present at concentrations up to 100 times higher than the iron concentration used (2.79 ppm). Other ions like $\mathrm{F}^{-}, \mathrm{Br}^{-}, \mathrm{I}^{-}, \mathrm{S}_{2} \mathrm{O}_{8}{ }^{2-}$, $\mathrm{CO}_{3}{ }^{2-}, \mathrm{S}_{2} \mathrm{O}_{5}{ }^{2-}, \mathrm{HC}_{8} \mathrm{H}_{4} \mathrm{O}_{4}-\mathrm{CH}_{3} \mathrm{COO}^{-}\left(50\right.$ times); $\mathrm{Co}^{2+}$ (10 times); $\mathrm{NO}_{2}^{-}, \mathrm{S}_{2} \mathrm{O}_{3}^{2-}, \mathrm{H}_{2} \mathrm{PO}_{4}^{-}\left(1\right.$ time) and $\mathrm{C}_{2} \mathrm{O}_{4}{ }^{2-}$ , $\mathrm{HPO}_{4}{ }^{2-}, \mathrm{Cu}^{2+}$ showed significant interference $(\mathrm{Er}>5 \%)$ under these experimental conditions.

Some results obtained are shown under the ideal conditions in table 1 , both for both the method presently developed and atomic absorption (standard addition method), for the total iron determination of the commercial pharmaceutical drug. Table 2 shows the results for two natural iron rocks with a comparative summary of both techniques.

Table 1. Experimental results obtained for the pharmaceutical drug by spectrophotometric and atomic absorption techniques

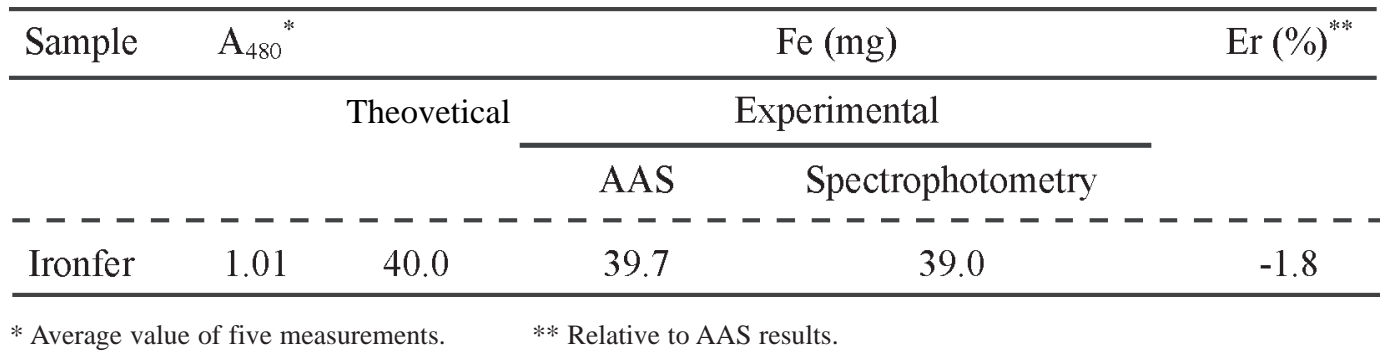

Table 2. Comparative results encountered for iron rocks through both techniques

\begin{tabular}{|c|c|c|c|c|}
\hline \multirow[t]{2}{*}{ Sample } & $\mathrm{A}_{480}{ }^{*}$ & \multicolumn{2}{|c|}{ Fe (ppm), stock solution } & \multirow[t]{2}{*}{$\operatorname{Er}(\%)$} \\
\hline & & AAS & Spectrophotom & \\
\hline$\overline{\text { Hematite }} 1$ & $1.0 \overline{1}$ & $\overline{129.6}$ & $---\overline{124 . \overline{6}}$ & $-\overline{-3.9}$ \\
\hline Hematite 2 & 1.03 & 151.2 & 149.4 & -1.1 \\
\hline
\end{tabular}

* Average values of five measurements. 
The comparison of the results obtained with this present spectrophotometric method with those from atomic absorption showed good agreement, within acceptable analytical limits $\left[\mathrm{E}_{\mathrm{r}}(\%) \leq 5\right]$, for these different tested materials (rocks and the pharmaceutical drug).

\section{Conclusions}

While the fading of the iron(III)/thiocyanate colour has always been a problem for analytical application of this system, under the conditions studied in the present work, we have demonstrated that rapid oxidation of iron(II) occurs in the system, followed by immediate reaction of the resulting iron(III) with thiocyanate ligands easily, generating very stable complexes. Some tests unpublished proved that hydrogen peroxide is a more satisfactory and cleaner oxidant for iron(II) than permanganate, persulfate or periodate ions in the thiocyanate determination of iron. However, excess of peroxide may cause a yellowish interfering colour due to oxidation products of the thiocyanate ligand. Direct addition of hydrogen peroxide to the reaction medium was abandoned during our studies.

Comparative tests (not shown here) about the oxidizing power of azide $\left(\mathrm{N}_{3}^{-}\right)$and thiocyanate $\left(\mathrm{SCN}^{-}\right)$ions showed that iron(II) is more easily oxidized (and complexed) by azide ligands in totally aqueous or mixed medium. Nevertheless, the thiocyanate system displays higher sensitivity (molar absorptivity) in acetone medium than the similar iron/azide system, in tetrahydrofuran or acetone. Certainly, the presence of dissolved oxygen in solvent could be the main responsible by oxidation process. Also, a higher concentration of iron probably will take longer time for iron(II) to be completely oxidized. In presence of high concentrations of acid, azide and thiocyanate ions have different behaviors or accessibility due its respectives ionization constants. Hydrazoic acid is weaker and more volatile than thiocyanic one. Another important difference between these involved systems (iron(III)/azide/THF and iron(III)/ thiocyanate/acetone) is their respective absorption spectrum: only the first one presents an interesting absorption band with a maximum absorbance about $400 \mathrm{~nm}$. In the thiocyanate system just the classical band $(480 \mathrm{~nm})$ can be observed.
Alternative methodologies for total iron determination in an unknown sample, as well as speciation studies, could be refreshed.

Some parameters that directly affect the reaction rate in this system, such as acidity, ligand concentration, temperature and presence of organic solvent, were carefully investigated. The optimized experimental conditions encountered for rapid oxidation and subsequent complexation

(determination of total iron) were: $\mathrm{C}_{\mathrm{HClO}_{4}}=30$ $\mathrm{mmol} \mathrm{L}{ }^{-1} ; \mathrm{C}_{\mathrm{SCN}^{-}}=350 \mathrm{mmol} \mathrm{L}^{-1} ; \mathrm{C}_{\text {acetone }}=70 \%(\mathrm{v} /$ v); $T=25{ }^{\circ} \mathrm{C} ; \ddot{e}_{\text {máx }}=480 \mathrm{~nm}$; reaction time $=5$ minutes.

Calibration, stability, precision and the effect of various ions studies were carried out for ferric complexes at $480 \mathrm{~nm}$, in the presence of acetone. The analytical curve for total iron determination obeys Beer's law ( $r=0.9993)$, and the value calculated for the average molar absorptivity $\left(2.10 \times 10^{4} \mathrm{~L} \mathrm{~cm}^{-1} \mathrm{~mol}^{-1}\right)$ showed the high potential of this system for analytical applications. The ideal concentration range for iron determination lies between 1 and $8 \mathrm{mg} \mathrm{L}^{-1}$. Good precision of the results was verified by suitable studies. As for interfering ions, only $\mathrm{NO}_{2}^{-}, \mathrm{S}_{2} \mathrm{O}_{3}{ }^{2-}, \mathrm{C}_{2} \mathrm{O}_{4}{ }^{2-}, \mathrm{HPO}_{4}{ }^{2-}$, $\mathrm{H}_{2} \mathrm{PO}_{4}^{-}, \mathrm{Co}^{2+}$ and $\mathrm{Cu}^{2+}$ showed some influence on iron determination through the proposed method. A commercial pharmaceutical product and two natural different rocks were tested as real samples for the metal determination. Atomic absorption was used for comparison purposes and the results obtained through these two techniques are in very good agreement.

Such results show the viability and the potential of this re-evaluated method as an alternative analytical procedure for the determination of iron cations with precision, low cost and accuracy.

\section{Acknowledgements}

The authors are grateful to the $\mathrm{CNPq}$ and FAPESP for financial support and to Dra. Cynthia M. de C. Prado Manso for linguistic advice.

Recebido em: 09/05/2005

Aceito em: 26/07/2005 
F. G. Martins, J. F. Andrade, A. C. Pimenta, L. M. Lourenço, J. R. M. Castro, V. R. Balbo. Estudo espectrofotométrico da oxidação de ferro no sistema ferro(II)/tiocianato/acetona e algumas aplicações analíticas

Resumo: A possibilidade de usar tiocianato para determinar ferro(II) e/ou ferro(III), em mistura de águaacetona, foi reexaminada como parte de um estudo sistemático e comparativo envolvendo complexos metálicos de ligantes pseudo-haletos. As condições experimentais foram otimizadas estudando-se alguns parâmetros que afetam a oxidação completa dos cátions ferrosos, a subseqüente complexação e estabilidade do sistema resultante. Nossos resultados mostraram a viabilidade e potencialidade desta metodologia simples como um procedimento analítico alternativo para se determinar cátions de ferro com elevada sensibilidade, precisão e exatidão. Realizaram-se estudos de calibração, estabilidade e repetitividade, verificando-se também o efeito de vários íons estranhos sobre as leituras de absorbância em $480 \mathrm{~nm}$. A curva analítica para a determinação de ferro total obedece à lei de Beer $(r=0,9993)$, mostrando uma sensibilidade mais alta (absortividade molar média de $2,10 \times 10^{4} \mathrm{~L} \mathrm{~mol}^{-1} \mathrm{~cm}^{-1}$ ) se comparada a outros ligantes tradicionais ou mesmo ao similar íon azoteto $\left(1,53 \times 10^{4} \mathrm{~L} \mathrm{~cm}^{-1} \mathrm{~mol}^{-1}\right.$, para os complexos de ferro-III/azoteto, em $70 \%$ (v/v) tetraidrofurano/água, a $396 \mathrm{~nm}$ ). Sob as condições experimentais otimizadas, é possível determinar ferro na faixa aproximada de 0,5 a 2 ppm (no intervalo de $15-65 \% \mathrm{~T}$ para aparelhagem mais antiga, cubetas de quartzo de 1,00 cm). Algumas aplicações analíticas foram testadas para diferentes materiais (minérios de ferro), incluindo-se também produtos farmacêuticos para anemia, cujos resultados foram comparados com determinações realizadas por absorção atômica. Concordâncias muito boas (erros < 5\%) foram verificadas entre essas duas diferentes técnicas, o que mostra a potencialidade das condições experimentais propostas para a determinação espectrofotométrica de ferro total. Ficou evidente a possibilidade de especiação do metal, com o auxílio de algum outro método que seja específico para apenas uma das espécies envolvidas.

Palavras-chave: sistema ferro(II/III)-tiocianato-acetona; oxidação; aplicações espectrofotométricas.

\section{References}

[1] G. O. Chierice, E. A. Neves, Polyhedron, 2 (1983) 31.

[2] E. A. Neves, J. F. Andrade, Polyhedron, 5 (1986) 717.

[3] N. Coichev, E. A. Neves, Polyhedron, 8 (1989) 641.

[4] J. F. Andrade, O. M. Guimarães, Anal. Chim. Acta, 271 (1993) 149.

[5] E. A. Neves, J. F. Andrade, G. O. Chierice, Anal. Chim. Acta, 155 (1983) 269.

[6] E. A. Neves, J. F. Andrade, G. O. Chierice, Anal. Lett., 18 (1985) 707.

[7] R. Luca, J. E. Bevilácqua, E. A. Neves, J. F. Andrade, Anal. Lett., 20 (1987) 389.

[8] O. M. Guimarães, J. F. Andrade, E. A. Neves, G. O., Chierice, Anal. Lett., 26 (1993) 2491.

[9] D. R. Carmo, J. F. Andrade, O. M. Guimarães, Anal. Lett., 28 (1995) 1897.

[10] L. M. Lourenço, Estudo espectrofotométrico do sistema crômio (III)/azoteto e seu aproveitamento analítico. 2003. 95f. Dissertação (Mestrado em Química) - FFCLRP, Universidade de São Paulo, Ribeirão Preto / SP.

[11] A.P.O. Sader, Estudo espectrofotométrico do sistema cobalto (II)/tiocianato e seu aproveitamento analítico. 2002. 91f. Dissertação (Mestrado em Química) - FFCLRP, Universidade de São Paulo, Ribeirão Preto / SP.

[12] C. J. Chacarolli, J. F. Andrade, O. M. Guimarães, V. R. Balbo, C. S. Venezuela, F. S. Teruel, Anal. Chim. Acta, 411 (2000) 217.
[13] A. C. Pimenta, J. F. Andrade, F. G. Martins, L. M. Lourenço. Formação de complexos no sistema ferro(III)/ azoteto/tetraidrofurano. 27 . Reunião Anual da SBQ, Salvador, SBQ, 2004. Resumo QA262.

[14] H. M. Sammour, A.T. Sheglila, F. A. Aly, Analyst, 102 (1977) 180.

[15] S. M. Sultan, E. Bishop, Analyst, 107 (1982) 1060.

[16] E. Merian, Metals and their compounds in the environmental, VCH, New York, 2000, chap. 14.

[17] B. Mason, Princípios de geoquímica, Polígono, São Paulo, 1966, chap. 3.

[18] E. L. Canto, Minerais, minérios, metais, Polêmica, São Paulo, 4th edn., 1997, chap.8.

[19] D. H. Andrews, R. J. Kokes, Química Geral, Editora da Universidade de São Paulo, São Paulo, 1968, chap. 23.

[20] S. Pehkonen, Y. Erel, M. R. Hoffmann, Environ. Sci. Technol., 26(9) (1992) 1731.

[21] M. Worwood, Anal. Chim. Acta, 259 (1997) 3.

[22] A. A. Paiva, P. H. C. Rondó, E. M. G Shinohara, Revista de Saúde Pública, 34(4) 2000, 421.

[23] R. C. Brasted, The halogens in comprehensive inorganic chemistry, D. Van Nostrand Company, New York, 1954, chap.9. [24] F. A. Cotton, G. Wilkinson, Advanced inorganic chemistry: a comprehensive text, Wiley-Interscience, New York, 6th edn., 1999, chap. 17.

[25] J. E. Huheey, Inorganic chemistry: principles of structure and 
reactivity, Haper \& Row, New York, 3rd edn., 1983, chap. 18. [26] S. Hirata, H. Yoshihara, A. Masato, Talanta, 49(5) (1999) 1059.

[27] V. A. Elrod, K. S. Johnson, K. H. Coale, Anal. Chem., 63(9) (1991) 893.
[28] J. Wang, S. Mannino, Analyst, 114 (1989) 643.

[29] L. L. Stookey, Anal. Chem., 42 (1970) 779.

[30] P. P. Carter, Anal. Biochem., 40 (1971) 450.

[31] S. Schäffer, P. Gareil, C. Dezael, D. Richard, J. Chromatogr., 740 (1996) 151. 